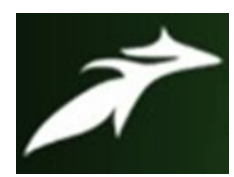

Kunche Gowthami et al, International Journal of Advances in Agricultural Science \& Technology,

Vol.8 Issue.10, October-2021, pg. 68-73

ISSN: $2348-1358$

Impact Factor: 6.057

NAAS Rating: 3.77

\title{
ADOPTION BEHAVIOUR OF BRINJAL GROWERS TOWARDS INTEGRATED PEST MANAGEMENT PRACTICES IN EAST GODAVARI DISTRICT OF ANDHRA PRADESH
}

\author{
Kunche Gowthami ${ }^{1}$ \\ (Researcher), M.Sc.Ag (Agricultural Extension and Communication) \\ Jahanara ${ }^{2}$ \\ (Head and Associate Professor), Department of Agricultural Extension and Communication, SHUATS (Prayagraj) \\ Syed H. Mazhar ${ }^{3}$ \\ (Associate Professor), Department of Agricultural Extension and Communication, SHUATS (Prayagraj)
} DOI: 10.47856/ijaast.2021.v08i10.008

\begin{abstract}
The present study was conducted in Korukonda and Ramchandrapuram division having prominent area under brinjal in East Godavari district by selecting 4 villages from each mandal for study. Total 72 brinjal growers were selected. The study revealed that personal and socio economic characteristics of the respondents education, , land holding, extension participation, area under brinjal, extension contact and mass media exposure were positively and significantly correlated with their level of adoption of IPM practices. The variable age, family type, annual income and occupation had negative and significant correlation with the adoption level. Availability of biopesticides, pheromone traps and light traps at reasonable price and at local places were the important suggestions made by brinjal growers. The other suggestions were insect organization of demonstration campaign for proper guidance on IPM practices and for identifying insect pest from state department of agriculture and state agricultural universities.
\end{abstract}

Keywords: Adoption, Integrated Pest Management (IPM), pheromone traps, insect, pest, biopesticides

\section{INTRODUCTION}

Brinjal (Solanum Melongena L.) a native species of South Asian origin, Brinjal or baingan, known as eggplant and Aubergine in North America and Europe respectively, is a very important common man's vegetable in India. It is often described as a poor man's vegetable because it is popular amongst small-scale farmers and low income consumers. A poor man's crop it might be, but brinjal is also called by some as the 'King of Vegetables'. It is featured in the dishes of virtually every household in India, regardless of food preferences, income levels and social status. Low in calories and high in nutrition, the vegetable has very high water content and is a very good source of fiber, calcium, phosphorus, folate, and vitamins $\mathrm{B}$ and $\mathrm{C}$. It is also used in ayurvedic medicine for curing diabetes, hypertension and obesity. In addition, dried brinjal shoots are used as fuel in rural areas. Brinjal has embedded itself deeply into the Indian culture. Numerous folk songs in Indian languages center on the humble vegetable. 


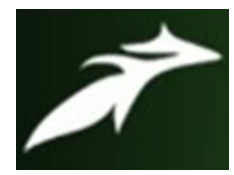

Kunche Gowthami et al, International Journal of Advances in Agricultural Science \& Technology, Vol.8 Issue.10, October-2021, pg. 68-73

ISSN: $2348-1358$ Impact Factor: 6.057

NAAS Rating: 3.77

Brinjal is grown on nearly 5,50,000 hectares in India, making the country the second largest producer after China with a $26 \%$ world production share. It is an important cash crop for more than 1.4 million small, marginal and resource-poor farmers. Brinjal, being a hardy crop that yields well even under drought conditions, is grown in almost all parts of the country. Major brinjal producing states include: West Bengal (23.69 \%), Orissa (15.75\%), Gujarat (11.14\%), Bihar (9.72\%) and Andhra Pradesh (2.97\%). In 2017-2018, During fiscal year 2020, the volume of brinjal production in India amounted to approximately 12.35 million metric tons. This was a slight decrease from the previous fiscal year, over 720 thousand hectares of agricultural land in the country .

IPM is not a single pest control method but rather, a series of pest management evaluations, decisions and controls. In practicing IPM, growers who are aware of the potential for pest infestation follow a four tiered approach. The four steps include: Action thresholds, monitoring and identifying pests, prevention, control. IPM strategies focus on an appropriate mixture of eco-friendly practices. It includes eco-friendly practices which are grouped as cultural, mechanical, biological and environmentally safe chemical.

\section{RESEARCH METHODOLOGY}

Descriptive research design has been pursued for this study. In this design, since they have already occurred, the researcher has no opportunity to influence the independent variables. Based on already revealed impacts, assumptions on the connection between independent and dependent variables are taken.

A structured interview schedule, consisting relevant questions related with the objectives of the study was prepared. Every precaution was taken to keep the language local and simple so as to get desired responses from the respondents.

\section{Objectives of the study}

1. To find out the relationship of selected characteristics of respondents with their adoption about integrated pest management practices. 


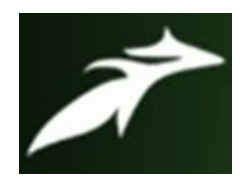

Kunche Gowthami et al, International Journal of Advances in Agricultural Science \& Technology,

Vol.8 Issue.10, October-2021, pg. 68-73

ISSN: $2348-1358$

Impact Factor: 6.057

NAAS Rating: 3.77

\section{RESULT \& DISCUSSION}

Relationship between the Adoption behavior of IPM and socio-economic characteristics of brinjal growers.

This section gives the association between the adoption behavior and socio-economic profile of the brinjal growers. For studying the association and contribution of independent variables towards dependent variable, the statistical tools namely correlation, multiple regression were employed and the results have been presented and discussed as below.

\begin{tabular}{|c|l|c|c|c|c|}
\hline $\begin{array}{c}\text { Variable } \\
\text { no }\end{array}$ & \multicolumn{1}{|c|}{ Variable name } & 'r' values & $\begin{array}{c}\text { Regression } \\
\text { coefficient }\end{array}$ & 't' values & 'P' values \\
\hline $\mathrm{X} 1$ & Age & 0.002 & -0.068 & -0.548 & 0.586 \\
\hline $\mathrm{X} 2$ & Education & 0.192 & $0.613^{* *}$ & $4.221^{* *}$ & 0.000 \\
\hline $\mathrm{X} 3$ & Caste & 0.070 & 0.042 & 0.357 & 0.723 \\
\hline $\mathrm{X} 4$ & Family type & -0.077 & -0.059 & -0.291 & 0.772 \\
\hline $\mathrm{X} 5$ & Family size & -0.001 & 0.016 & 0.080 & 0.936 \\
\hline $\mathrm{X} 6$ & Annual income & -0.069 & -0.091 & -0.648 & 0.520 \\
\hline $\mathrm{X} 7$ & Land holding & 0.138 & 0.214 & 1.330 & 0.189 \\
\hline $\mathrm{X} 8$ & Occupation & 0.008 & -0.140 & -0.922 & 0.360 \\
\hline $\mathrm{X} 9$ & Experience & 0.141 & 0.030 & 0.239 & 0.812 \\
\hline & & Area under brinjal & & & \\
\hline
\end{tabular}




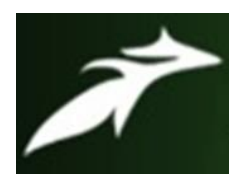

Kunche Gowthami et al, International Journal of Advances in Agricultural Science \& Technology,

Vol.8 Issue.10, October-2021, pg. 68-73

ISSN: $2348-1358$

Impact Factor: 6.057

NAAS Rating: 3.77

\begin{tabular}{|c|l|c|c|c|c|}
\hline $\mathrm{X} 11$ & Social participation & -0.005 & 0.075 & 0.560 & 0.578 \\
\hline $\mathrm{X} 12$ & Extension participation & 0.110 & 0.153 & 1.325 & 0.190 \\
\hline $\mathrm{X} 13$ & Extension contact & 0.057 & $0.271^{*}$ & $1.986^{*}$ & 0.052 \\
\hline $\mathrm{X} 14$ & Mass media exposure & 0.365 & $0.610^{* *}$ & $4.772 * *$ & 0.000 \\
\hline
\end{tabular}

$$
\begin{array}{ccc}
\mathbf{R}^{2}=\mathbf{0 . 5 0 1} & & \text { F value }=\mathbf{4 . 0 9 5} \\
* & = & \text { Significant at } 5 \% \text { level } \\
* * & = & \text { Significant at } 1 \% \text { level } \\
\text { NS } & = & \text { Non }- \text { significant }
\end{array}
$$

It could be seen from the above Table 1 among the 14 selected variables of the study $\left(\mathrm{X}_{10}\right)$, Area under brinjal and $\left(\mathrm{X}_{13}\right)$, Extension contact exhibited a positive relationship at a five per cent level of Significance. In addition to that $\left(\mathrm{X}_{2}\right)$, Education and $\left(\mathrm{X}_{14}\right)$, Mass media exposure shows positive relationship at one per cent level of significance. Meanwhile age $\left(\mathrm{X}_{1}\right)$, category $\left(\mathrm{X}_{3}\right)$, Family type $\left(\mathrm{X}_{4}\right)$, Family size $\left(\mathrm{X}_{5}\right)$, Annual income $\left(\mathrm{X}_{6}\right)$, Land holding $\left(\mathrm{X}_{6}\right)$, Occupation $\left(\mathrm{X}_{8}\right)$, Experience $\left(\mathrm{X}_{9}\right)$, Social participation $\left(\mathrm{X}_{11}\right)$, Extension participation $\left(\mathrm{X}_{12}\right)$ showed a non-significant relationship with the adoption behaviour of brinjal growers.

It could be deciphered that the adoption behaviour of brinjal growers was the result of their Education, Area under brinjal, Extension contact and Mass media exposure shows a positive relationship at a five per cent level of significance. Family type, Family size, Annual income, Social participation had negative relationship with the Adoption behavior. All most all other variable shows non-significant relationship with Adoption behavior. 


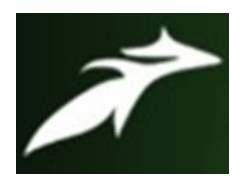

Kunche Gowthami et al, International Journal of Advances in Agricultural Science \& Technology, Vol.8 Issue.10, October-2021, pg. 68-73

The $\mathrm{R}^{2}$ value was 0.510 , which indicated that 51.00 per cent variation in the adoption behavior was explained by the fourteen variables which are selected for the study. The prediction equation was fitted for the adoption behavior of the respondents is $\mathrm{Y}_{1}=$ $115.77-0.068(\mathrm{X} 1)+0.613(\mathrm{X} 2)+0.042(\mathrm{X} 3)-0.059(\mathrm{X} 4)+0.016(\mathrm{X} 5)-0.091(\mathrm{X} 6)+0.214$ $(\mathrm{X} 7)-0.140(\mathrm{X} 8)+0.030(\mathrm{X} 9)+0.292(\mathrm{X} 10)+0.075(\mathrm{X} 11)+0.153(\mathrm{X} 12)+0.271(\mathrm{X} 13)$ $+0.610(\mathrm{X} 14)$.

It could be indicated from the above equation that one unit increase in the Education(X2), area under brinjal (X10), Extension contact $\left(\mathrm{X}_{13}\right)$ and Mass media exposure (X14) by a unit result in the adoption behavior of the respondents by, 0.613 , $0.292,0.271$ and 0.610 respectively. From the study it is concluded that Education, area under brinjal, Extension contact and Mass media exposure have contributed high level of adoption behavior.

\section{CONCLUSION}

From the above findings it can be concluded that the Brinjal respondents had medium access to Extension participation and Extension contact, Education, Mass media Exposure, Area under brinjal and Extension contact have high level of Adoption Behavior and the overall Adoption Behavior of the brinjal growers is Medium level. However, very low adoption was found in respect of the practices namely grazing of sheeps and goats, avoid high dose of nitrogenous fertilizer, use of pheromone traps sticky pans, determination of ETL, seed treatment and seedling treatment. 


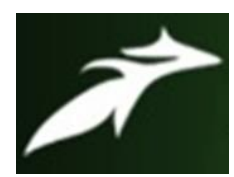

Kunche Gowthami et al, International Journal of Advances in Agricultural Science \& Technology,

Vol.8 Issue.10, October-2021, pg. 68-73

ISSN: $2348-1358$

Impact Factor: 6.057

NAAS Rating: 3.77

\section{REFERENCES}

[1]. Akter, M., Islam, M.N., Afrin, H., Shammi, S.A., Begum and Haque, S. (2016). Comparative profitability analysis of IPM and non IPM technology vegetable cultivation in selected areas. Progressive Agriculture, Vol.27(3): pp.311-319.

[2]. Dar, S.A., Wani, A.R., Muneer., Sofia and Pathana, S.S (2017).IPM for brinjal shoot and fruit borer (leucinodes Orbonalis) - A review. Indian Journal of Entomology, Vol.79(2): pp.130-137.

[3]. Maurya, A.S., Yadav , R.N., Singh, D.K., Singh, D., Singh, V.K, Prerana, K. and Singh, K.M. (2017) Socio-Economic Status of Brinjal Growers in Bulandshahr District of Western Uttar Pradesh, India . International Journal of Current Microbiology and Applied Sciences, Vol .6 (8) : pp361-365.

[4]. Nayan, R. \& Syed, H.M. (2016) Adoption Behaviour of Brinjal (Solanum melongena L) Growers in Nawada Block of Nawada District of Bihar. International Journal of Engineering Technology, Management and Applied Science, Vol.4(9).

[5]. Sasane, G.K ., Jagdale, U.D. and Khule, R.P.(2010) Knowledge and adoption of brinjal management practices by the farmers. Agriculture update, Vol.5(3\&4): 495-197. 